\title{
inorganics
}

ISSN 2304-6740

www.mdpi.com/journal/inorganics

Article

\section{Fully Oxidized and Mixed-Valent Polyoxomolybdates Structured by Bisphosphonates with Pendant Pyridine Groups: Synthesis, Structure and Photochromic Properties}

\author{
Olivier Oms ${ }^{1, *}$, Tarik Benali ${ }^{1}$, Jérome Marrot ${ }^{1}$, Pierre Mialane ${ }^{1}$, Marin Puget ${ }^{2}$, \\ Hélène Serier-Brault ${ }^{2}$, Philippe Deniard ${ }^{2}$, Rémi Dessapt ${ }^{2, *}$ and Anne Dolbecq ${ }^{1, *}$
}

1 Institut Lavoisier de Versailles, UMR8180, Université de Versailles St Quentin en Yvelines, 45 Avenue des Etats Unis, 78035 Versailles cedex, France; E-Mails: tarik.marrec@gmail.com (T.B.); jerome.marrot@uvsq.fr (J.M.); pierre.mialane@uvsq.fr (P.M.)

2 Institut des Matériaux Jean-Rouxel, Université de Nantes, CNRS, 2 Rue de la Houssinière, BP 32229, 44322 Nantes cedex, France; E-Mails: marinpuget@gmail.com (M.P.);

Helene.Brault@cnrs-imn.fr (H.S.-B.); Philippe.Deniard@cnrs-imn.fr (P.D.)

* Authors to whom correspondence should be addressed; E-Mails: olivier.oms@uvsq.fr (O.O.); Remi.Dessapt@cnrs-imn.fr (R.D.); anne.dolbecq@uvsq.fr (A.D.);

Tel.: +33-139-254-383 (A.D.); Fax: +33-139-254-381 (A.D.).

Academic Editors: Greta Ricarda Patzke and Pierre-Emmanuel Car

Received: 16 April 2015 / Accepted: 29 May 2015 / Published: 11 June 2015

\begin{abstract}
Hybrid organic-inorganic polyoxometalates (POMs) were synthesized in water by the reaction of a $\mathrm{Mo}^{\mathrm{VI}}$ precursor with bisphosphonate ligands functionalized by pyridine groups. The fully oxidized POM $\left[\left(\mathrm{Mo}_{3} \mathrm{OI}_{8}\right)_{2}(\mathrm{O})\left(\mathrm{O}_{3} \mathrm{PC}(\mathrm{O})\left(\mathrm{C}_{3} \mathrm{H}_{6} \mathrm{NH}_{2} \mathrm{CH}_{2} \mathrm{C}_{5} \mathrm{H}_{4} \mathrm{NH}\right) \mathrm{PO}_{3}\right)_{2}\right]^{4-}$ has been isolated as water insoluble pure $\mathrm{Na}$ salt $\left(\mathbf{N a M o} \mathbf{A l}_{6}(\mathbf{A l e}-\mathbf{4 P y})_{2}\right)$ or mixed $\mathrm{Na} / \mathrm{K}$ salt $\left(\mathbf{N a K M o}(\mathbf{A l e}-\mathbf{4 P y})_{2}\right)$ and their structure solved using single-crystal $\mathrm{X}$-ray diffraction. The mixed-valent complex $\left[\left(\mathrm{Mo}_{2} \mathrm{O}_{4}\right)\left(\mathrm{Mo}_{2} \mathrm{VI}_{6}\right)_{2}\left\{\mathrm{O}_{3} \mathrm{PC}(\mathrm{O})\left(\mathrm{C}_{3} \mathrm{H}_{6} \mathrm{~N}\left(\mathrm{CH}_{2} \mathrm{C}_{5} \mathrm{H}_{4} \mathrm{~N}\right)_{2}\left(\mathrm{Mo}^{\mathrm{VI}} \mathrm{O}_{3}\right)\right) \mathrm{PO}_{3}\right\}_{2}\right]^{8-}$ was obtained as an ammonium salt $\left(\mathbf{N H}_{4} \mathbf{M o}_{6}\left(\mathbf{A l e P y}_{2} \mathbf{M o}\right)_{2}\right)$, in the presence of a reducing agent (hydrazine). ${ }^{31} \mathrm{P}$ NMR spectroscopic studies in aqueous media have allowed determining the $\mathrm{pH}$ stability domain of $\mathbf{N H}_{4} \mathrm{Mo}_{6}\left(\mathrm{AlePy}_{2} \mathrm{Mo}_{2}\right.$. $\mathrm{NaMo}_{6}(\mathrm{Ale}-4 \mathrm{Py})_{2}$ and $\mathrm{NaKMo}_{6}(\mathrm{Ale}-4 \mathrm{Py})_{2}$ exhibit remarkable solid-state photochromic properties in ambient conditions. Under UV excitation, they develop a very fast color-change from white to deep purple and proved to be the fastest photochromic organoammonium/POM systems. The coloration kinetics has been fully quantified for both salts and is discussed in light of the hydrogen-bonding networks.
\end{abstract}


Keywords: bisphosphonate; hydrogen bonds; molybdenum; photochromism; polyoxometalate

\section{Introduction}

Polyoxometalates (POMs) are discrete soluble metal oxide fragments of d-block transition metals in high oxidation states $\left(\mathrm{W}^{\mathrm{V}, \mathrm{VI}}, \mathrm{Mo}^{\mathrm{V}, \mathrm{VI}}, \mathrm{V}^{\mathrm{IV}, \mathrm{V}}\right)$ with a wide range of properties going from magnetism [1] to biology [2] and catalysis [3]. Among these properties, photochromism attracts increasing interest due to the potential applications of POM-based photoresponsive molecular materials as reversible memory photodevices [4]. Reversible color-change effects under UV irradiation have been first evidenced on alkylammonium polyoxomolybdates [5,6]. The mechanism has been rationalized considering the transfer of an electron from an $\mathrm{O}$ atom of the POM unit to a $\mathrm{Mo}^{\mathrm{VI}}$ center, coupled with the transfer of a hydrogen atom (see below). These materials are ionic crystals combining anionic POMs and cationic alkylammonium counter-ions. However, an alternative and attractive approach to get functionalized POM-based materials consists in the covalent attachment of organic ligands directly onto the POM core [7]. It has indeed been demonstrated that the presence of covalently bonded organic ligands can bring new functionalities and allow the elaboration of unique materials and devices [8], as demonstrated by the characterization of surfaces patterned with POMs [9,10], the synthesis of fluorescent [11] and catalytic [12] POMs, or the elaboration of extended frameworks based on POM building units [13]. We have developed for several years the functionalization of POMs by bisphosphonates (BPs) with the general formula $\mathrm{H}_{2} \mathrm{O}_{3} \mathrm{PC}\left(\mathrm{R}_{1}\right)\left(\mathrm{R}_{2}\right) \mathrm{PO}_{3} \mathrm{H}_{2}\left(\mathrm{R}_{1}=\mathrm{H}, \mathrm{OH}\right)$ [14]. Once deprotonated, BPs act as multidentate ligands and can form stable POM complexes [15]. We initiated a few years ago a study on the synthesis of polyoxomolybdates with grafted BPs, starting with $\mathrm{Mo}^{\mathrm{V}} / \mathrm{BP}$ complexes. Alendronic acid (Ale, Scheme 1) and its aminophenol derivative were reacted with $\mathrm{Mo}^{\mathrm{V}}$ ions, leading to low nuclearity complexes [16]. The reaction of $\mathrm{Mo}^{\mathrm{VI}}$ ions with Ale was then investigated and we showed that the synthetic $\mathrm{pH}$ governs the formation of one complex over the other. The mononuclear POM $\left[\left(\mathrm{MoO}_{2}\right)(\mathrm{Ale})_{2}\right]^{6-}\left(\mathrm{Mo}(\mathrm{Ale})_{2}\right)$ [17] was isolated at $\mathrm{pH} 7.5$, the hexanuclear complex $\left[\left(\mathrm{Mo}_{3} \mathrm{O}_{8}\right)_{2} \mathrm{O}(\mathrm{Ale})_{2}\right]^{6-}\left(\mathrm{Mo6}(\mathrm{Ale})_{2}\right)$ [18] at $\mathrm{pH}=4.5$ and the dodecanuclear complex $\left[\left(\mathrm{Mo}_{3} \mathrm{O}_{8}\right)_{4}(\mathrm{Ale})_{4}\right]^{8-}\left(\mathrm{Mo}{ }_{2}(\mathrm{Ale})_{4}\right)$ at $\mathrm{pH}=3.0[16]$. The hexa and dodecanuclear hybrid POMs possess highly efficient solid-state photochromic properties which are brought by the grafting of the organic ligand [18]. We then decided to post-functionalize the Ale ligand with pyridine groups with the aim to explore its chelating properties towards additional metal ions and study their influence on the structure and properties of the molybdobisphosphonate complexes. We thus report here our results with two BP ligands bearing one or two pyridine groups, abbreviated Ale-4Py and AlePy2, respectively (Scheme 1). The photochromic properties of the $\mathrm{Mo}^{\mathrm{VI}}$ derivatives with Ale-4Py have been studied and are compared with those of related complexes. 


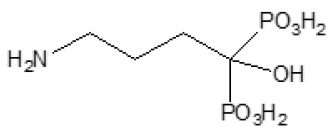

Ale

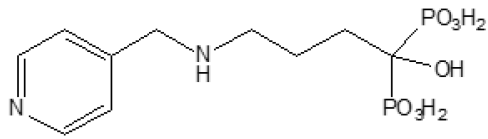

Ale-4Py

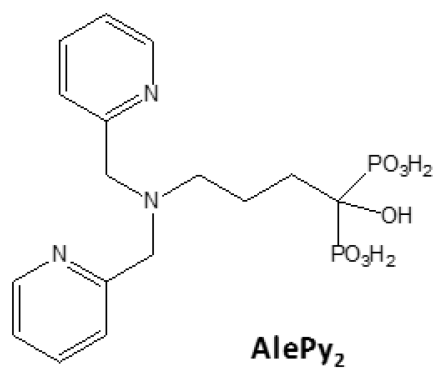

Scheme 1. Structure and abbreviations of the ligands used in this work.

\section{Results and Discussion}

\subsection{Synthesis and Characterization}

The new BP Ale-4Py ligand has been obtained by coupling Ale and 4-pyridinecarboxaldehyde, followed by the reduction of the resulting imine derivative. We explored the synthesis of hybrid polyoxomolybdates functionalized by BP ligands, namely Ale-4Py and AlePy2, using two different synthetic protocols (Scheme 2). The first one consists in reacting an aqueous solution of $\mathrm{Mo}^{\mathrm{VI}}$ oxoanions with Ale-4Py. The $\mathrm{pH}$ is set at 3.1 by addition of $2 \mathrm{M} \mathrm{HCl}$ and the solution is heated to $80{ }^{\circ} \mathrm{C}$ for $30 \mathrm{~min}$. White crystals of the pure $\mathrm{Na}\left(\mathbf{N a M o}_{6}(\mathbf{A l e}-\mathbf{4 P y})_{2}\right)$ and of the mixed Na/K salt (NaKMo6 (Ale-4Py) $\left.)_{2}\right)$ of the hybrid POMs were isolated after slow evaporation and characterized by single crystal X-ray diffraction and elemental analysis (see below). Surprisingly, the X-ray study revealed the presence of the hexanuclear anion $\left[\left(\mathrm{Mo}_{3} \mathrm{O}_{8}\right)_{2}(\mathrm{O})\left(\mathrm{O}_{3} \mathrm{PC}(\mathrm{O})\left(\mathrm{C}_{3} \mathrm{H}_{6} \mathrm{NH}_{2} \mathrm{CH}_{2} \mathrm{C}_{5} \mathrm{H}_{4} \mathrm{NH}\right) \mathrm{PO}_{3}\right)_{2}\right]^{4-}\left(\mathbf{M o}_{6}(\right.$ Ale-4Py) $)$. Indeed, the crystallization of a dodecanuclear POM of general formula $\mathrm{Mo}_{12}(\mathrm{BP})_{4}$ was expected as these species were shown to be stable at $\mathrm{pH} 3$ while the formation of the hexanuclear POMs Mo6(BP) 2 (BP $=$ Ale, $\mathrm{O}_{3} \mathrm{PC}\left(\mathrm{C}_{3} \mathrm{H}_{6} \mathrm{NRR} \mathrm{R}^{\prime \prime}\right)(\mathrm{O}) \mathrm{PO}_{3}$ with $\mathrm{R}, \mathrm{R}$ ', $\mathrm{R}$ ” $=\mathrm{H}$ or $\left.\mathrm{CH}_{3}\right)$ occurs at $\mathrm{pH} \sim 6$ [18].

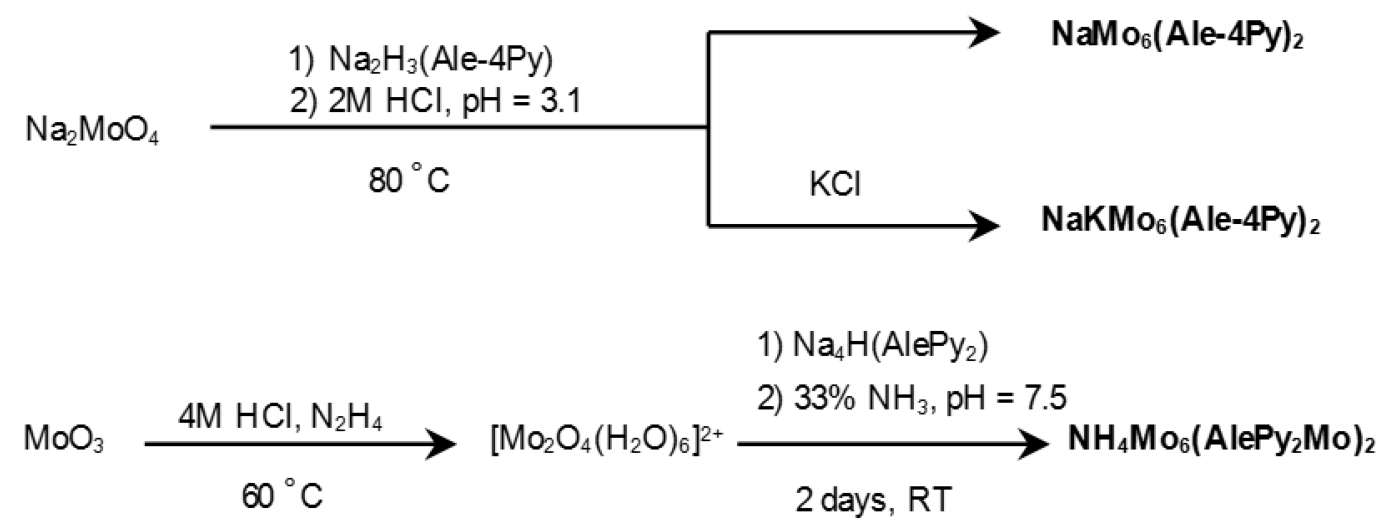

Scheme 2. Synthetic pathways.

The second synthetic pathway consists in using a solution of $\left[\mathrm{Mo}_{2} \mathrm{O}_{4}\left(\mathrm{H}_{2} \mathrm{O}\right)_{6}\right]^{2+}$ ions prepared by reduction of $\mathrm{MoO}_{3}$ by hydrazine in $4 \mathrm{M} \mathrm{HCl}$. AlePy2 is added in the solution and the $\mathrm{pH}$ is adjusted to 7.5 by addition of aqueous ammonium hydroxide. An abundant precipitate forms and progressively redissolves while stirring for two days at room temperature. Red crystals (Figure 1) are isolated after slow evaporation of the resulting solution. The formula of the hybrid POM, 
$\left[\left(\mathrm{Mo}_{2} \mathrm{O}_{4}\right)\left(\mathrm{Mo}_{2}{ }_{2} \mathrm{O}_{6}\right)_{2}\left\{\mathrm{O}_{3} \mathrm{PC}(\mathrm{O})\left(\mathrm{C}_{3} \mathrm{H}_{6} \mathrm{~N}\left(\mathrm{CH}_{2} \mathrm{C}_{5} \mathrm{H}_{4} \mathrm{~N}\right)_{2}\left(\mathrm{Mo}^{\mathrm{VI}} \mathrm{O}_{3}\right)\right) \mathrm{PO}_{3}\right\}_{2}\right]^{8-}$ ( $\mathbf{M o}_{6}\left(\mathrm{AlePy}_{2} \mathbf{M o}_{2}\right)$ has been deduced from single crystal X-ray analysis (see below) and confirmed by elemental analysis. The mixed-valent anion contains two $\mathrm{Mo}^{\mathrm{V}}$ and six $\mathrm{Mo}^{\mathrm{VI}}$ ions, which are formed by slow reoxidation in air of the $\mathrm{Mo}^{\mathrm{V}}$ ions of the reacting solution. Such reoxidation has been previously observed $[16,19,20]$. The red color of the complex is correlated to the presence of the dimeric unit $\left\{\mathrm{Mo}_{2} \mathrm{O}_{4}\right\}$, which can be found in oxomolybdenum(V) clusters isolated in organic solvents [21] as well as in cyclic POMs and $\varepsilon$-Keggin type species synthesized in aqueous solutions [14], and is the indication of electron localization while the blue color of mixed-valent Mo species is the sign of electron delocalization [22].

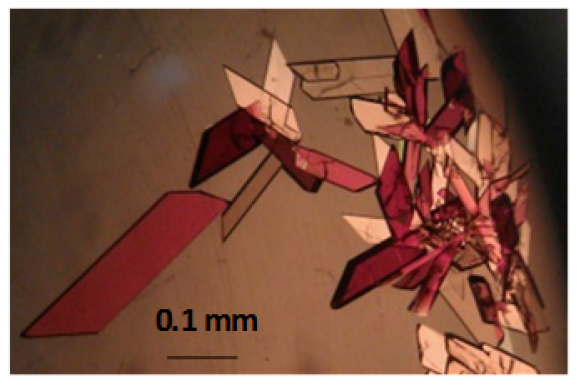

Figure 1. Picture of the crystals of $\mathbf{N H}_{4} \mathbf{M o}_{6}\left(\mathrm{AlePy}_{2} \mathbf{M o}_{2}\right.$ in the synthetic medium.

$\mathrm{NaMo}_{6}\left(\right.$ Ale-4Py)$_{2}$ and $\mathrm{NaKMo}_{6}(\mathrm{Ale}-4 \mathrm{Py})_{2}$ are insoluble in all common solvents. Therefore, it was not possible to investigate their stability in solution by ${ }^{31} \mathrm{P}$ NMR spectroscopy. Nevertheless, it has been possible to record the ${ }^{31} \mathrm{P}$ NMR spectra of the synthetic solutions (Figure 2a). Three peaks around $22 \mathrm{ppm}$ are observed which can be tentatively attributed to the presence of conformers in equilibrium in solution [18].

(a)

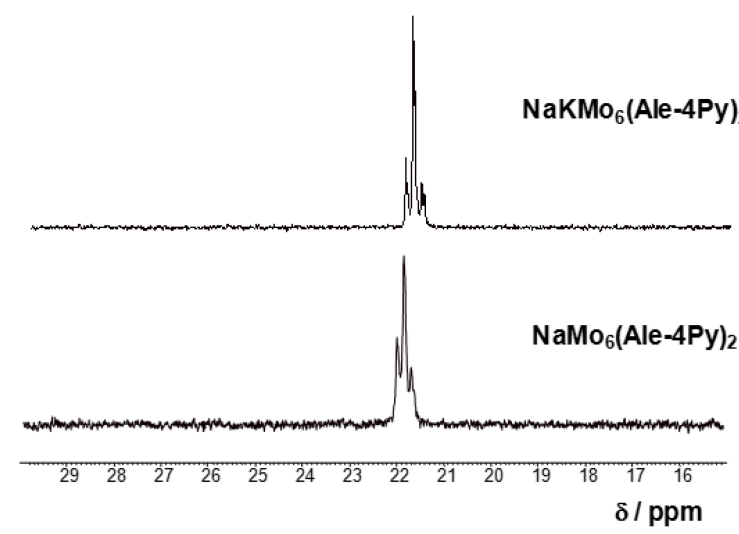

(b)

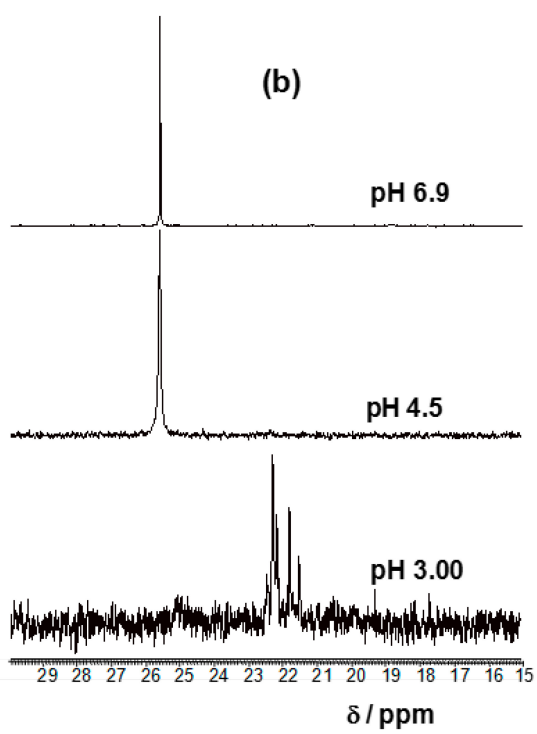

Figure 2. ${ }^{31} \mathrm{P}$ NMR spectra of a) the synthetic medium of $\mathrm{NaMo}_{6}(\mathrm{Ale}-4 \mathrm{Py})_{2}$ and $\mathrm{NaKMo}_{6}(\mathrm{Ale}-4 \mathrm{Py})_{2}$ and b) an aqueous solution of $\mathbf{N H}_{4} \mathbf{M o}_{6}\left(\mathrm{AlePy}_{2} \mathbf{M o}_{2}\right.$ at various $\mathrm{pH}$.

Crystals of $\mathbf{N H}_{4} \mathbf{M o}_{6}\left(\mathbf{A l e P y}_{2} \mathbf{M o}\right)_{2}$ have been dissolved in $\mathrm{D}_{2} \mathrm{O}$ and the $\mathrm{pH}$ adjusted to 7 . A single peak at $25.6 \mathrm{ppm}$ is observed by ${ }^{31} \mathrm{P}\left\{{ }^{1} \mathrm{H}\right\}$ NMR (Figure $2 \mathrm{~b}$ ). This indicates that the two $\mathrm{P}$ atoms in each BP ligand are magnetically equivalent although they appear inequivalent in the crystal structure 
(Figure S1). This is in contrast also with the observation of doublets at 30.1 and $26.2 \mathrm{ppm}$ on the

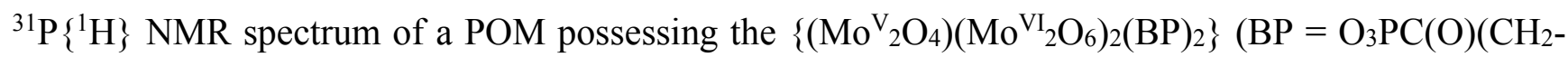

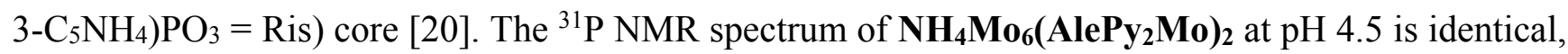
showing the stability of the POM at this $\mathrm{pH}$. In contrast, when the $\mathrm{pH}$ decreases to 3 , the evolution of the ${ }^{31} \mathrm{P}$ NMR spectrum together with the appearance of a blue color clearly indicate the decomposition of the POM.

\subsection{Structures}

The hexanuclear anion $\left[\left(\mathrm{Mo}^{\mathrm{VI}}{ }_{3} \mathrm{O}_{8}\right)_{2}(\mathrm{O})\left(\mathrm{O}_{3} \mathrm{PC}(\mathrm{O})\left(\mathrm{C}_{3} \mathrm{H}_{6} \mathrm{NH}_{2} \mathrm{CH}_{2} \mathrm{C}_{5} \mathrm{H}_{4} \mathrm{NH}\right) \mathrm{PO}_{3}\right)_{2}\right]^{4-}\left(\mathbf{M o}_{6}(\mathbf{A l e}-\mathbf{4 P y})_{2}\right)$, common in the structures of $\mathrm{NaMo}_{6}\left(\mathrm{Ale}_{\mathbf{4}} \mathbf{4 P y}\right)_{2}$ and $\mathrm{NaKMo}_{6}(\mathrm{Ale}-4 \mathrm{Py})_{2}$, contains two trinuclear $\left\{\mathrm{Mo}_{3} \mathrm{O}_{8}\right\}$ fragments connected by a central oxo bridge (Figure 3), encountered also in structures reported with etidronate [23], alendronate [17,24] and its methyl derivatives [18]. Each trinuclear unit is built of two face-sharing octahedra which share also a corner with a third $\mathrm{Mo}^{\mathrm{VI}}$ octahedron. The three octahedra are linked to one bisphosphonate ligand via four Mo-O-P bonds with the phosphonate groups and one Mo-O-C bond with the deprotonated hydroxo group. Two conformations have been previously observed for the hexanuclear complexes of general formula $\left[\left(\mathrm{Mo}_{3} \mathrm{VI}_{3}\right)_{2}(\mathrm{O})(\mathrm{BP})_{2}\right]^{n^{-}}[14]$. In the $A$ conformer (Figure $3 \mathrm{a}$ ), the six $\mathrm{Mo}^{\mathrm{VI}}$ ions are approximately coplanar. This conformer is the most frequently encountered, and is found in particular in $\mathrm{Rb}_{0.25}\left(\mathrm{NH}_{4}\right)_{5.75}\left[\left(\mathrm{MoVI}_{3} \mathrm{O}_{8}\right)_{2}(\mathrm{O})(\mathrm{Ale})_{2}\right]$ [18]. The $B$ conformer (Figure 3b), observed for example in $\mathrm{Na} 6\left[\left(\mathrm{Mo}_{3} \mathrm{O}_{8}\right)_{2}(\mathrm{O})(\mathrm{Ale})_{2}\right]$ [24], results from a rotation around the central oxygen atom of a trimeric unit, so that the three $\mathrm{Mo}^{\mathrm{VI}}$ ions of a trimeric unit are located in a plane perpendicular to the three $\mathrm{Mo}^{\mathrm{VI}}$ ions of the other trimeric unit. The conformers are very close in energy, and the stabilization of one conformer or another depends on the inter- and intramolecular interactions governed by the crystal packing. A comparison of the structures of the anions in NaMo6(Ale-4Py)2 and NaKMo6(Ale-4Py)2 with those of the alendronate derivatives shows that the Mo6(Ale-4Py)2 entities in NaMo6(Ale-4Py) 2 and NaKMo6(Ale-4Py) 2 adopt the $B$ conformation. The orientation of the organic ligand is slightly different from one compound to the other.

In the unit cell, the anions alternate with alkali counter-ions $\left(4 \mathrm{Na}^{+}\right.$ion in $\mathbf{N a M o 6}(\mathbf{A l e}-4 \mathbf{P y})_{2}$ and $3.5 \mathrm{~K}^{+}$and $0.5 \mathrm{Na}^{+}$in NaKMo6(Ale-4Py) 2 ) and the crystal packing thus appear quite different in the two structures (Figure S2). Despite this, the hydrogen bond networks involving the POM units appear remarkably similar. Both intra and intermolecular hydrogen bonds are observed between the protonated amino and pyridine groups of the Ale-4Py ligands and bridging oxygen atoms of the POM cores or crystallized water molecules (Figure 4 and Table S1). The structure of NaMo6(Ale-4Py)2 contains one crystallographically independent Mo6(Ale-4Py)2 anion. As shown in Figure 4a, two of them are connected together into a supramolecular dimer $\left\{\mathbf{M o}_{6}(\mathbf{A l e}-\mathbf{4 P y})_{2}\right\}_{2}$ via two H-bonds involving two of the four pyridinium groups (the other two being connected to water molecules). Each dimer also develops eight additional $\mathrm{N}-\mathrm{H} \cdots \mathrm{O}$ interactions: four of them involve the protonated amino groups of the four Ale-4Py ligands and the oxygen atoms of the two Mo6(Ale-4Py) 2 units, while the other four connect the protonated amino groups with water molecules. 

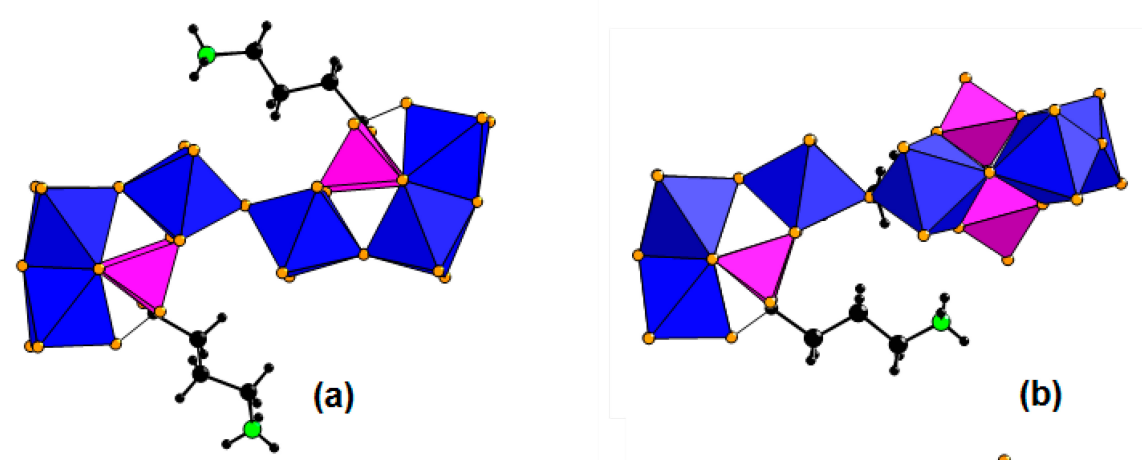

(b)

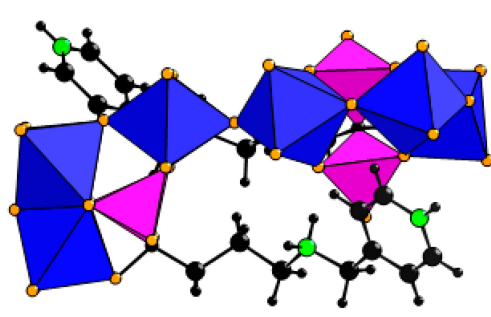

(c)

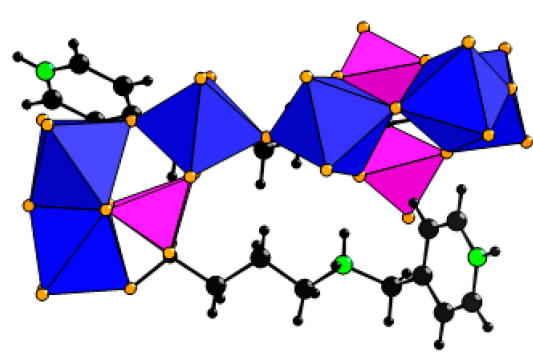

(d)

Figure 3. Mixed polyhedral/ball-and-stick representation of the hexanuclear POM of general formula $\left[\left(\mathrm{Mo}_{3} \mathrm{VI}_{8}\right)_{2}(\mathrm{O})(\mathrm{BP})_{2}\right]^{n^{-}}$in (a) $\mathrm{Rb}_{0.25}\left(\mathrm{NH}_{4}\right)_{5.75}\left[\left(\mathrm{Mo}_{3} \mathrm{OI}_{8}\right)_{2}(\mathrm{O})(\mathrm{Ale})_{2}\right]^{18}(A$ conformation), (b) $\mathrm{Na}_{6}\left[\left(\mathrm{Mo}_{3} \mathrm{OI}_{8}\right)_{2}(\mathrm{O})(\mathrm{Ale})_{2}\right]^{24}$ ( $B$ conformation), (c) NaMo6(Ale-4Py) 2 and (d) NaKMo6(Ale-4Py) 2; blue octahedra: $\mathrm{Mo}^{\mathrm{VI}} \mathrm{O}_{6}$, pink tetrahedra: $\mathrm{PO}_{4}$, orange spheres: O, black spheres: $\mathrm{C}$, green spheres: $\mathrm{N}$.

The structure of $\mathbf{N a K M o}_{6}(\mathbf{A l e}-\mathbf{4 P y})_{2}$ is built upon two crystallographically independent $\mathbf{M o}_{6}(\mathbf{A l e}-\mathbf{4 P y})_{2}$ units which are assembled into two supramolecular dimers (Figure 4b). The relative arrangement of anions within the dimers is as in NaMo6(Ale-4Py) 2 , and therefore, very similar N-H $\cdots \mathrm{O}$ contacts are developed.

The $\mathrm{Mo}_{6}\left(\mathrm{AlePy}_{2} \mathrm{Mo}_{2}\right)_{2} \mathrm{POM}$ contains a mixed-valent $\left\{\left(\mathrm{Mo}_{2} \mathrm{O}_{4}\right)\left(\mathrm{Mo}_{2} \mathrm{OI}_{6}\right)_{2}(\mathrm{BP})_{2}\right\}$ core (Figure 5). Two face-sharing $\mathrm{Mo}^{\mathrm{VI}}$ octahedra are connected symmetrically to a $\left\{\mathrm{Mo}_{2} \mathrm{~V}_{4}\right\}$ dimeric unit via a common oxygen atom and two pentadentate AlePy2 ligands. We can note that AlePy2 and Ale-4Py behave very differently. Indeed, while in Ale-4Py the aminopyridine fragments cannot act as chelating groups, the two pyridine and the alkylammino groups of AlePy2 can strongly bind to an additional metal ion. This is highlighted by the fact that in NaKMo6(Ale-4Py) 2 and NaMo6(Ale-4Py) 2 the pyridine and alkylammonium groups do not act as a ligand. In contrast in $\mathbf{M o}_{6}\left(\mathbf{A l e P y}_{2} \mathbf{M o}_{2}\right.$, the nitrogen atoms of the two pyridine and of the amino groups of the AlePy2 ligand are bound to an isolated $\mathrm{Mo}^{\mathrm{VI}}$ ion in octahedral coordination. The coordination sphere of this ion is completed by three terminal oxo groups. Valence bond calculations confirm the oxidation states of the Mo ions in this octanuclear complex (Figure S1). It can be noticed that the oxygen atoms of the POM develop hydrogen bonding interactions exclusively with water molecules (Figure S3a). In the solid, there is a segregation of the organic and inorganic parts with the formation of double layers of Mo6 clusters at $z$ $=1 / 2$ and Mo-organic regions at $z=0$ (Figure S3b). 
(a)

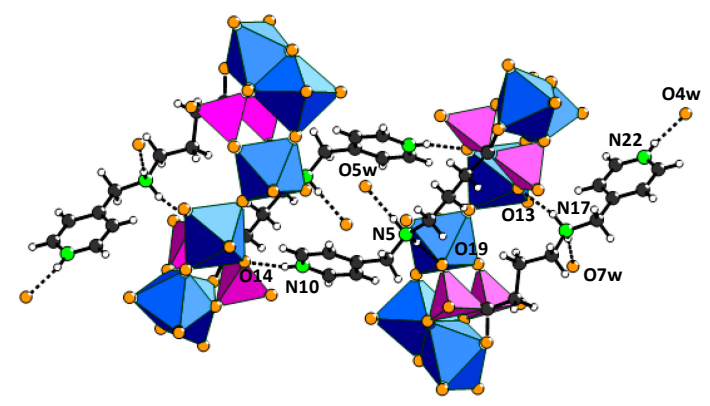

(b)
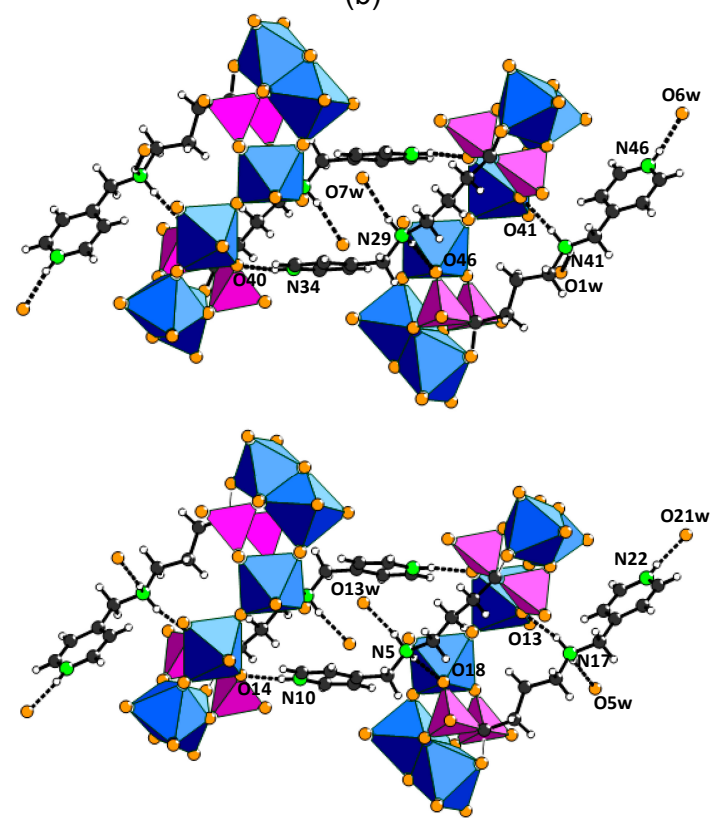

Figure 4. Hydrogen bonding schemes involving the supramolecular dimers Mo6(Ale$\left.4 \mathrm{Py})_{2}\right\}_{2}$ in (a) $\mathbf{N a M o}_{6}(\text { Ale-4Py) })_{2}$ and (b) NaKMo6(Ale-4Py) ${ }_{2}$.

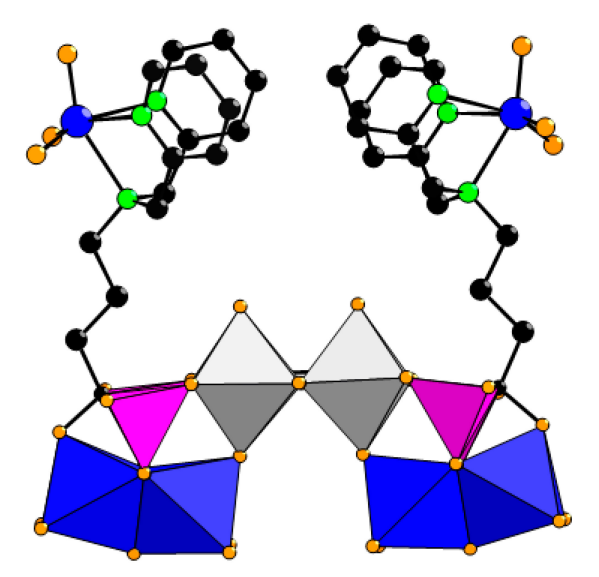

Figure 5. Mixed polyhedral/ball-and-stick representation of the mixed-valent $\mathrm{POM}$ $\left[\left(\mathrm{Mo}_{2} \mathrm{O}_{4}\right)\left(\mathrm{Mo}_{2} \mathrm{VI}_{2}\right)_{2}\left\{\mathrm{O}_{3} \mathrm{PC}(\mathrm{O})\left(\mathrm{C}_{3} \mathrm{H}_{6} \mathrm{~N}_{(}\left(\mathrm{CH}_{2} \mathrm{C}_{5} \mathrm{H}_{4} \mathrm{~N}\right)_{2}\left(\mathrm{Mo}^{\mathrm{VI}} \mathrm{O}_{3}\right)\right) \mathrm{PO}_{3}\right\}_{2}\right]^{8-}$ in $\mathbf{N H}_{4} \mathbf{M o}_{6}\left(\mathrm{AlePy}_{2} \mathbf{M o}_{2}\right.$; blue octahedra: $\mathrm{Mo}^{\mathrm{VI}} \mathrm{O}_{6}$, grey octahedra: $\mathrm{Mo}^{\mathrm{V}} \mathrm{O}_{6}$, blue spheres: $\mathrm{Mo}^{\mathrm{VI}}$, pink tetrahedra: $\mathrm{P}$, orange spheres: $\mathrm{O}$, black spheres: $\mathrm{C}$, green spheres: $\mathrm{N}$; hydrogen atoms have been omitted for clarity. 


\subsection{Solid-State Photochromic Properties}

The solid-state photochromic properties of NaMo6(Ale-4Py) ${ }_{2}$ and $\mathrm{NaKMo}_{6}(\mathrm{Ale}-4 \mathrm{Py})_{2}$ have been thoroughly investigated in ambient conditions by diffuse reflectance spectroscopy. Under low-power UV excitation at $\lambda_{\mathrm{ex}}=365 \mathrm{~nm}(3.34 \mathrm{eV})$, the two compounds exhibit strong photochromic responses. The color of the white microcrystalline powders gradually shifts to deep purple with a remarkable coloration contrast, and finally reaches an eye-detected saturation level after only 20 min (Figure 6a and Figure S4a for NaKMo6(Ale-4Py)2 and NaMo6(Ale-4Py)2, respectively). As displayed in Figure $6 \mathrm{~b}$, the color change of $\mathrm{NaKMo}_{6}(\mathrm{Ale}-\mathbf{4 P y})_{2}$ deals with the growth of a broad absorption band in the visible range at $\lambda_{\max }=508 \mathrm{~nm}(2.44 \mathrm{eV})$ that mainly dictates the photogenerated hue, and a second very less-intense absorption band rising up at $\sim 750 \mathrm{~nm}(1.65 \mathrm{eV})$. Similar absorption bands are also observed for $\mathrm{NaMo}_{6}\left(\mathrm{Ale}_{\mathbf{4}} \mathbf{4 P y}\right)_{2}$ (Figure S4b). It is worth noting that these bands are quite comparable with those of other photochromic $\operatorname{Mo6}(\mathrm{BP})_{2}$ compounds [18], and then, they well characterize the photoreduced Mo6 core. In such photochromic organoammonium/POM systems, the UV excitation transfers an electron from an $\mathrm{O}$ atom of the $\mathrm{POM}$ unit to the adjacent $\mathrm{Mo}^{6+}$ site [5,25]. This electron/hole pair segregation is coupled with the transfer of a hydrogen atom from the ammonium group to an adjacent $\left\{\mathrm{MoO}_{6}\right\}$ octahedron. The $\mathrm{H}$ atom moves along the hydrogen bond creating a $\left\{\mathrm{Mo}^{5+}(\mathrm{OH}) \mathrm{O}_{5}\right\}$ site. The coloration is then due to the photoreduction of $\mathrm{Mo}^{6+}\left(4 \mathrm{~d}^{0}\right)$ to $\mathrm{Mo}^{5+}\left(4 \mathrm{~d}^{1}\right)$ cations and occurs via $\mathrm{d}-\mathrm{d}$ transitions and/or $\mathrm{Mo}^{6+} / \mathrm{Mo}^{5+}$ intervalence transfers. The photocoloration rate is strongly correlated to the strength of the $\mathrm{N}^{+}-\mathrm{H}$ bonds considering that, the lower the dissociation energy of the $\mathrm{N}^{+}-\mathrm{H}$ bond, the faster the coloration speed [6].

The coloration kinetics of $\mathrm{NaMo}_{6}(\mathrm{Ale}-4 \mathrm{Py})_{2}$ and $\mathrm{NaKMo}_{6}(\mathrm{Ale}-4 \mathrm{Py})_{2}$ has been quantified by monitoring the evolution of their reflectivity values versus the UV irradiation time $(\mathrm{R}(t))$. According to the photocoloration kinetics model of organoammonium/POM systems, the decrease of $R^{\lambda \max }(t)$ (i.e., the reflectivity at the wavelength of the maximum photogenerated absorption in the visible) with the UV irradiation time is correlated to the decrease of the concentration of reducible $\mathrm{Mo}^{6+}$ cations, according to a pseudo second-order kinetic law [6]. Herein, the $\mathrm{R}^{508}(t) v$ s. $t$ curves for NaMo6(Ale4Py $)_{2}$ and $\mathbf{N a K M o}_{6}\left(\right.$ Ale-4Py) 2 are perfectly fitted as $\mathrm{R}^{508}(t)=\mathrm{a} /(\mathrm{b} t+1)+\mathrm{R}^{508}(\infty)$ (Figure $\left.6 \mathrm{c}\right) . \mathrm{R}^{508}(\infty)$ is the reflectivity value at the end of the photochromic process, that is at $t=\infty$. The a parameter is defined as $\mathrm{a}=\mathrm{R}^{508}(0)-\mathrm{R}^{508}(\infty)$, i.e. the difference between the reflectivity values just before UV illumination $(t=0)$ and at $t=\infty$. The $\mathrm{b}$ parameter is defined as $\mathrm{b}=\mathrm{k}^{c} \times \mathrm{C}_{6+, \mathrm{r}}(0)$, where $\mathrm{k}^{c}$ is the coloration rate constant, and $\mathrm{C}_{6+, \mathrm{r}}(0)$ is the initial concentration of photoreducible $\mathrm{Mo}^{6+}$ centers per unit volume. The details of the coloration kinetic parameters are given in Table S2. NaMo6(Ale-4Py) 2 and $\mathbf{N a K M o}_{6}($ Ale-4Py) 2 exhibit a remarkably fast photocoloration rates well characterized by a very short coloration half-time ( $t_{1 / 2}=0.37 \mathrm{~min}$ for both compounds). The very fast photoreduction rate of the $\mathrm{Mo}^{6+}$ ions is also well assessed by monitoring the evolution of the photoreduction degree $\mathrm{Y}(t)$ which reaches $\mathbf{9 8 \%}$ for $\mathbf{N a M o}_{6}\left(\mathbf{A l e}_{\mathbf{4}} \mathbf{4 P y}\right)_{2}$ and $\mathbf{9 7 \%}$ for $\mathbf{N a K M o}$ (Ale-4Py) $)_{2}$ after only 20 min of UV irradiation (Figure S5).

In addition, for two hybrid materials, $i$ and $j$ built upon the same POM unit (then which develop the same photogenerated absorption bands), the relative coloration rate constants $k^{c} i / k_{j}^{c}$ can be extracted from the ratio $b_{i} a_{j} / b_{j} a_{i}$, to compare their coloration rates [6]. Here, $k^{c}$ NaMo6(Ale-4Py)2 $/ k^{c}$ NaKMo6(Ale-4Py)2 $=1.1$, and both compounds exhibit the same photocoloration rates. This quite evidences that in these two hybrid 
systems that contain the same Mo6(Ale-4Py)2 anion and very similar H-bonding networks, the intrinsic photochromic process is not influenced by the packing with the other alkali countercations. Noticeably, $\mathrm{NaMo}_{6}($ Ale-4Py)2 and NaKMo6(Ale-4Py)2 exhibit remarkably improved solid-state photochromic performances compared to those of Mo6-Ale that was, to date, the fastest photochromic members of the Mo6(BP)2 series $[18,26]$ (Table S2) (for example, the coloration rate constant ratio $k_{\text {NaKMo6(Ale-4Py) } 4 / \mathbf{K}^{c}{ }_{\text {Mo6-Ale }}}$ reaches 10.6). Consequently, these two new compounds are the most efficient known photochromic organoammonium/POM systems (Table 1). It should be reasonably assumed that the very high photochromic performances of $\mathrm{NaMo}_{6}\left(\mathrm{Ale}_{\mathbf{4}} \mathbf{4 P y}\right)_{2}$ and $\mathrm{NaKMo}_{6}(\mathrm{Ale}-4 \mathrm{Py})_{2}$ should originate from a beneficial combination of three main factors that are: (i) the presence of the easily photoreducible Mo6 core [18], (ii) a great number of $\mathrm{N}-\mathrm{H} \cdots \mathrm{O}$ contacts between the Mo6(Ale-4Py) $)_{2}$ units and the organoammonium groups of the Ale-4Py ligands, and (iii) the implication in the H-bonding interactions of the diprotonated amino group which possesses a low dissociation energy of the $\mathrm{N}^{+}-\mathrm{H}$ bond [6].

Table 1. Comparison of the $\mathrm{t}_{1 / 2}$ values for various photochromic organoammonium/POM systems.

\begin{tabular}{|c|c|c|c|}
\hline Compound & $\lambda_{\max }(\mathrm{nm})^{\mathrm{a}}$ & $t_{1 / 2}(\min )^{b}$ & Ref. \\
\hline $\mathrm{NaMo}_{6}(\mathrm{Ale}-4 \mathrm{Py})_{2}$ & 508 & 0.37 & this work \\
\hline $\mathrm{NaKMo}_{6}(\mathrm{Ale}-4 \mathrm{Py})_{2}$ & 508 & 0.37 & this work \\
\hline $\mathrm{Mo}_{6}(\mathrm{Ale})_{2}$ & 508 & 2.87 & [18] \\
\hline $\operatorname{Mo}_{6}\left(\operatorname{Ale}-1 C_{a}\right)_{2}$ & 508 & 31.25 & [18] \\
\hline $\operatorname{Mo}_{6}\left(\text { Ale- } 1 C_{b}\right)_{2}$ & 508 & 4.78 & [18] \\
\hline $\mathrm{Mo}_{6}(\text { Ale-2C })_{2}$ & 508 & 12.82 & [18] \\
\hline $\operatorname{Mo}_{6}(1 \mathrm{C}-\mathrm{Ale})_{2} \mathrm{Mo}_{6}(\mathrm{Ris})_{2}$ & 508 & 5.71 & [18] \\
\hline $\mathrm{Mo}_{6}(\mathrm{Ris})_{2}$ & 508 & 14.89 & {$[26]$} \\
\hline $\mathrm{Mo}_{12}(\mathrm{Ale})_{4}$ & 464 & 8.20 & {$[18]$} \\
\hline $\operatorname{Mo}_{12}\left(\operatorname{Ale}-1 C_{a}\right)_{4}$ & 464 & 5.44 & [18] \\
\hline $\operatorname{Mo}_{12}(\operatorname{Ale}-2 C)_{4}$ & 464 & 51.81 & [18] \\
\hline$\left(\mathrm{H}_{2} \mathrm{DABCO}\right)_{2}\left(\mathrm{NH}_{4}\right)_{2}\left[\mathrm{Mo}_{8} \mathrm{O}_{27}\right]$ & 525 & 37.0 & {$[6]$} \\
\hline$\left(\mathrm{H}_{2} \mathrm{DABCO}\right)_{2}\left(\mathrm{H}_{2} \mathrm{pipz}\right)\left[\mathrm{Mo}_{8} \mathrm{O}_{27}\right]$ & 525 & 5.6 & [6] \\
\hline$\left(\mathrm{H}_{2} \text { pipz }\right)_{3}\left[\mathrm{Mo}_{8} \mathrm{O}_{27}\right]$ & 525 & 7.8 & [6] \\
\hline$\left(\mathrm{H}_{2} \mathrm{DABCO}\right)_{2}(\mathrm{HDMA})_{0.5} \mathrm{Na}_{0.75}\left[\mathrm{Mo}_{8} \mathrm{O}_{27}\right]$ & 525 & 0.8 & [6] \\
\hline
\end{tabular}

${ }^{a}$ Photoinduced absorption band wavelength. ${ }^{\mathrm{b}}$ Coloration kinetic half-life time ( $\left.\mathrm{min}\right)$.

$\mathrm{NaMo}_{6}(\mathrm{Ale}-4 \mathrm{Py})_{2}$ and $\mathrm{NaKMo}_{6}(\text { Ale-4Py)})_{2}$ show reversible color-change effects. The bleaching is correlated to the back oxidation of the $\mathrm{Mo}^{5+}$ cations by $\mathrm{O}_{2}$ in ambient conditions [27]. After switching off the UV irradiation, the bleaching occurs slowly in air and at room temperature. No color change occurs when the colored samples are kept in $\mathrm{O}_{2}$ free atmosphere, and at the opposite the bleaching is much faster when samples are exposed to $\mathrm{O}_{2}$ flux. The fading process is also strongly accelerated by keeping the samples in air under moderate heating at $40{ }^{\circ} \mathrm{C}$ (the deep purple color disappears after a few minutes). To date, about 15 coloration/fading cycles at room temperature as well as at $40{ }^{\circ} \mathrm{C}$ can be performed without detecting any fatigue resistance with naked eyes. 
(a)

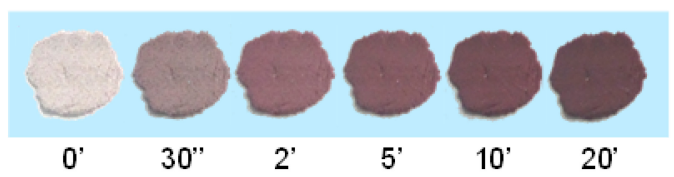

(b)

Energy (eV)

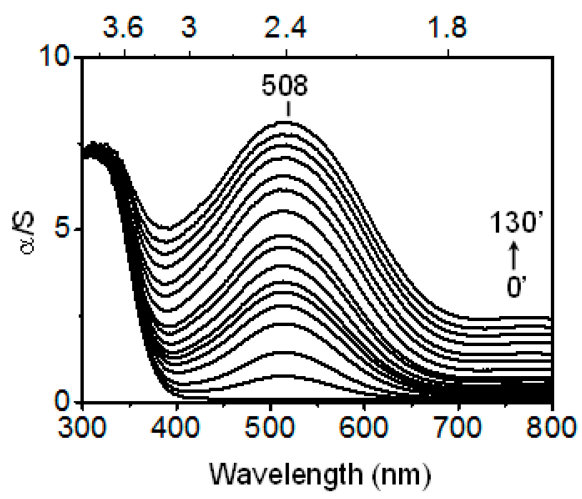

(c)

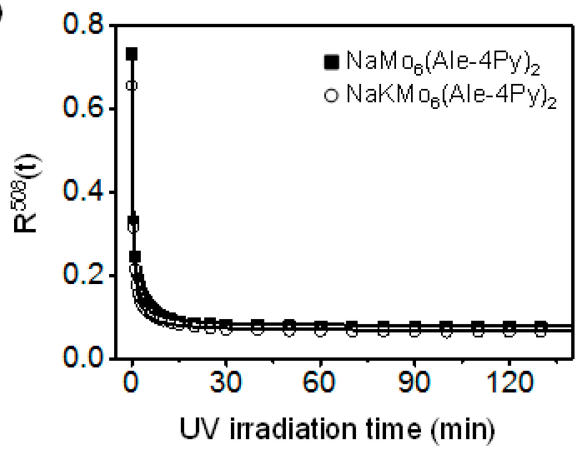

Figure 6. (a) Photographs of the powder of $\mathrm{NaKMo}_{6}(\mathrm{Ale}-4 \mathrm{Py})_{2}$ at different UV irradiation time (in min). (b) Evolution of the photo-generated absorption in NaKMo6(Ale-4Py) 2 after $0,0.5,1,2,3,4,5,7,10,15,20,30,40,60,80,100$ and 130 min of UV irradiation $\left(\lambda_{\text {ex }}=\right.$ $365 \mathrm{~nm})$. (c) Comparison of the $\mathrm{R}^{508}(t)$ vs. $t$ plots for $\mathbf{N a M o}_{6}(\mathbf{A l e}-4 \mathrm{Py})_{2}$ ( $\left.\mathbf{\square}\right)$, and $\mathrm{NaKMo}_{6}\left(\mathrm{Ale}_{\mathbf{4}}-\mathrm{Py}_{2}(\mathrm{O})\right.$. The lines show the fits of the plots according to rate law $\mathrm{R}^{508}(t)=$ $\mathrm{a} /(\mathrm{b} t+1)+\left(\mathrm{R}^{508}(0)-\mathrm{a}\right)$.

\section{Experimental Section}

\subsection{General}

The alendronic acid $\mathrm{H}_{2} \mathrm{O}_{3} \mathrm{PC}(\mathrm{OH})\left(\mathrm{C}_{3} \mathrm{H}_{6} \mathrm{NH}_{2}\right) \mathrm{PO}_{3} \mathrm{H}_{2}$ (Ale) [27] and its derivative $\mathrm{Na}_{4}\left[\mathrm{O}_{3} \mathrm{PC}(\mathrm{OH})\left(\mathrm{C}_{3} \mathrm{H}_{6} \mathrm{~N}\left(\mathrm{CH}_{2} \mathrm{C}_{5} \mathrm{H}_{4} \mathrm{~N}\right)_{2}\right) \mathrm{PO}_{3}\right]\left(\mathrm{Na}_{4} \mathrm{HAlePy}\right)$ [28] were synthesized according to reported procedures. All other chemicals were used as purchased without purification. Ale-4Py and AlePy2 were reacted with $\mathrm{Mo}^{\mathrm{VI}}$ and $\mathrm{Mo}^{\mathrm{V}}$ precursors. However, only the reactions of Ale-4Py with $\mathrm{Mo}^{\mathrm{VI}}$ and $\mathrm{AlePy}_{2}$ with $\mathrm{Mo}^{\mathrm{V}}$ led to crystalline compounds which could be characterized by single-crystal X-ray diffraction analysis.

\subsection{Synthesis of $\mathrm{Na}_{2}\left[\left(\mathrm{HO}_{3} \mathrm{P}\right)_{2}(\mathrm{OH}) \mathrm{C}\left(\mathrm{C}_{3} \mathrm{H}_{6} \mathrm{NHCH}_{2}\left(\mathrm{C}_{5} \mathrm{H}_{4} \mathrm{~N}\right)\right]\left(\mathrm{Na}_{2} \mathrm{H}_{3} \mathrm{Ale}-4 \mathrm{Py}\right)\right.$}

Alendronic acid $(1.5 \mathrm{~g}, 6 \mathrm{mmol})$ and triethylamine $(1.6 \mathrm{~mL}, 12 \mathrm{mmol})$ were stirred at room temperature in $36 \mathrm{~mL}$ of $\mathrm{MeOH}$ until complete dissolution. Then, 4-pyridinecarboxaldehyde $(0.62 \mathrm{~mL}$, 
$6.6 \mathrm{mmol}$ ) was added to the mixture. The solution was stirred at reflux for $2 \mathrm{~h}$. and then allowed to cool down to room temperature. After slow addition of (TBA)BH $4(1.549 \mathrm{~g}, 6 \mathrm{mmol})$, the resulting mixture was refluxed overnight. The solution was then concentrated to about $10 \mathrm{~mL}$ and NaPF $6(2.022 \mathrm{~g}$, $12 \mathrm{mmol}$ ) was added. A white precipitate appeared instantly. The solid was filtered under vacuum and washed with $\mathrm{MeOH}$ and $\mathrm{Et}_{2} \mathrm{O}$. The ligand (1.612 g, yield 70\%) was used without further purification. ${ }^{31} \mathrm{P}$ NMR (200 MHz, D $\left.2 \mathrm{O}\right): \delta$ 17.7. ${ }^{1} \mathrm{H}$ NMR $\left(200 \mathrm{MHz}, \mathrm{D}_{2} \mathrm{O}\right): \delta 8.47$ (d, 2H, $\left.{ }^{3} J=5.41 \mathrm{~Hz}\right), 7.40$ (d, $\left.2 \mathrm{H},{ }^{3} \mathrm{~J}=5.41 \mathrm{~Hz}\right), 4.18(\mathrm{~s}, 2 \mathrm{H}), 3.05\left(\mathrm{~m}, 2 \mathrm{H}, \mathrm{N}-\mathrm{CH}_{2}-\mathrm{CH}_{2}\right), 1.91\left(\mathrm{~m}, 4 \mathrm{H}, \mathrm{N}-\mathrm{CH}_{2}-\mathrm{CH}_{2}-\mathrm{CH}_{2}\right) . \mathrm{IR}(\mathrm{KBr}$ pellets): $v\left(\mathrm{~cm}^{-1}\right)=3192(\mathrm{w}), 2968(\mathrm{w}), 2950(\mathrm{w}), 1610(\mathrm{~m}), 1501(\mathrm{~m}), 1424(\mathrm{~m}), 1381(\mathrm{w}), 1224(\mathrm{~m})$, 1191 (m), 1141 (s), 1122 (s), 1071 (vs), 1036 (vs), 959 (s), 930 (s), 882 (s), 844 (s), 810 (m), 787 (m), $673(\mathrm{~s}), 605(\mathrm{~m}), 589(\mathrm{~m}), 556(\mathrm{~m}), 541(\mathrm{~m})$.

\subsection{Synthesis of $\mathrm{Na}_{4}\left[\left(\mathrm{Mo}_{3} \mathrm{OI}_{3}\right)_{2}(\mathrm{O})\left(\mathrm{O}_{3} \mathrm{PC}(\mathrm{O})\left(\mathrm{C}_{3} \mathrm{H}_{6} \mathrm{NH}_{2} \mathrm{CH}_{2} \mathrm{C}_{5} \mathrm{H}_{4} \mathrm{NH}\right) \mathrm{PO}_{3}\right)_{2}\right] .14 \mathrm{H}_{2} \mathrm{O}$ (NaMo $($ Ale-4Py)}

To a solution of $\mathrm{Na}_{2} \mathrm{MoO}_{4}(0.291 \mathrm{~g}, 1.2 \mathrm{mmol})$ in $10 \mathrm{~mL}$ of water was added $\mathrm{Na}_{2} \mathrm{H}_{3}$ (Ale-4Py) $(0.154 \mathrm{~g}$, $0.4 \mathrm{mmol}$ ). The $\mathrm{pH}$ was adjusted to 3.1 with $2 \mathrm{M} \mathrm{HCl}$ and the mixture was stirred at $80{ }^{\circ} \mathrm{C}$ for $30 \mathrm{~min}$. A fine powder was then eliminated by centrifugation $(0.134 \mathrm{~g})$ and the filtrate was left to evaporate at room temperature. The IR spectrum of the powder shows the presence of Mo-O and P-O vibrations close to the vibrations found in $\mathrm{Mo}_{12}(\mathrm{BP})_{4}$ species. After one month, white crystals (yield $0.037 \mathrm{~g}$; $10 \%$ based on Mo) suitable for X-ray diffraction studies were collected by filtration. The formation of the white insoluble powder explains the low yield of the synthesis.

IR (KBr pellets): $v\left(\mathrm{~cm}^{-1}\right)=3361(\mathrm{br}), 3082(\mathrm{~s}), 2832(\mathrm{~m}), 2788(\mathrm{~m}), 1644$ (s), 1624 (s), $1508(\mathrm{~m})$, 1467 (m), 1252 (w), 1137 (s), 1067 (s), 1015 (s), 907 (vs), 872 (vs), 815 (s), 675 (s), 548 (s). Anal. calcd. for $\mathrm{C}_{20} \mathrm{H}_{58} \mathrm{~N}_{4} \mathrm{Mo}_{6} \mathrm{Na}_{4} \mathrm{O}_{45} \mathrm{P}_{4}$ (1866.16 g.mol ${ }^{-1}$ ) (found): C 12.87 (12.60), H 3.13 (2.95), N 3.00 (2.94). EDX analyses confirm the values of the $\mathrm{Mo} / \mathrm{P}$ and $\mathrm{Mo} / \mathrm{Na}$ ratios.

\subsection{Synthesis of $\mathrm{Na}_{0.5} \mathrm{~K}_{3.5}\left[\left(\mathrm{Mo}_{3} \mathrm{VI}_{3}\right)_{2}(\mathrm{O})\left(\mathrm{O}_{3} \mathrm{PC}(\mathrm{O})\left(\mathrm{C}_{3} \mathrm{H}_{6} \mathrm{NH}_{2} \mathrm{CH}_{2} \mathrm{C}_{5} \mathrm{H}_{4} \mathrm{NH}\right) \mathrm{PO}_{3}\right)_{2}\right] .13 \mathrm{H}_{2} \mathrm{O}$}

\section{(NaKMo (Ale-4Py) $\left._{2}\right)$}

To a solution of $\mathrm{Na}_{2} \mathrm{MoO}_{4}(0.291 \mathrm{~g}, 1.2 \mathrm{mmol})$ in $10 \mathrm{~mL}$ of water was added $\mathrm{Na}_{2} \mathrm{H}_{3}$ (Ale-4Py) $(0.154 \mathrm{~g}$, $0.4 \mathrm{mmol}$ ). The $\mathrm{pH}$ was adjusted to 3.1 with $2 \mathrm{M} \mathrm{HCl}$ and the mixture was stirred at $80{ }^{\circ} \mathrm{C}$ for 30 minutes. A fine powder was then eliminated by centrifugation. $\mathrm{KCl}(0.100 \mathrm{~g})$ was added to the filtrate and the solution was left to evaporate at room temperature. After one month, white crystals (yield $0.056 \mathrm{~g} ; 15 \%$ based on Mo) suitable for X-ray diffraction studies were collected by filtration.

IR (KBr pellets): $v\left(\mathrm{~cm}^{-1}\right)=3365$ (br), 3082 (s), 2832 (m), 2789 (m), 1644 (s), 1626 (s), 1509 (m), 1468 (m), 1256 (w), 1137 (s), 1065 (s), 1016 (s), 907 (vs), 871 (vs), 811 (s), 678 (s), 551 (s). Anal. calcd. for $\mathrm{C}_{20} \mathrm{H}_{56} \mathrm{~N}_{4} \mathrm{~K}_{3.5} \mathrm{Mo}_{6} \mathrm{Na}_{0.5} \mathrm{O}_{44} \mathrm{P}_{4}$ (1904.53 g.mol ${ }^{-1}$ ) (found): $\mathrm{C} 12.61$ (12.50), H 2.96 (2.82), N 2.94 (2.85). EDX analyses confirm the values of the Mo/P, Mo/K and Mo/Na ratios.

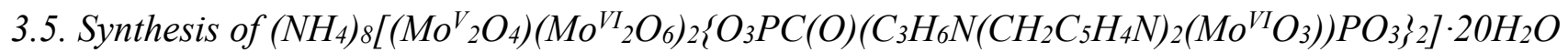

\section{$\left(\mathrm{NH}_{4} \mathrm{Mo}_{6}\left(\mathrm{AlePy}_{2} \mathrm{Mo}\right)_{2}\right)$}

A $0.1 \mathrm{M}$ solution of $\left[\mathrm{Mo}_{2} \mathrm{O}_{4}\left(\mathrm{H}_{2} \mathrm{O}\right)_{6}\right]^{2+}$ was prepared as previously reported [19] by reduction of $\mathrm{MoO}_{3}$ by $\mathrm{N}_{2} \mathrm{H}_{4}$ in $4 \mathrm{M}$ HCl. Na4HAlePy2 $(0.325 \mathrm{~g}, 0.21 \mathrm{mmol})$ was added in aqueous 
$\left[\mathrm{Mo}_{2} \mathrm{O}_{4}\left(\mathrm{H}_{2} \mathrm{O}\right)_{6}\right]^{2+}(0.1 \mathrm{M}, 6.25 \mathrm{~mL}, 0.625 \mathrm{mmol})$. A green precipitate appeared. Aqueous ammonium hydroxide (33\%) was added dropwise to $\mathrm{pH}$ 7.5. An orange precipitate was formed. The beaker was covered with a watch glass and the mixture was stirred for 2 days until the solution progressively turned limpid. The deep red solution was filtered, and left to evaporate at room temperature after addition of $\mathrm{NH}_{4} \mathrm{Br}$ (1.2 g, $\left.12.24 \mathrm{mmol}\right)$. Red crystals were collected by filtration two days later $(0.095 \mathrm{~g}$, yield 24\% based on Mo). Elemental analysis calcd. (found) for $\mathrm{C}_{32} \mathrm{H}_{108} \mathrm{~N}_{14} \mathrm{Mo}_{8} \mathrm{O}_{56} \mathrm{P}_{4}\left(2477 \mathrm{~g} \mathrm{~mol}^{-1}\right)$ : C 15.52 (15.20), H 4.39 (4.04), N 7.92 (8.42), Mo 30.98 (30.01), P 5.00 (4.91). IR ( $\left./ \mathrm{cm}^{-1}\right): 1638$ (m), 1606 (m), 1419 (s), 1314 (w), $1283(\mathrm{w}), 1142$ (sh), 1123 (s), 1075 (sh), 1052 (s), 1013 (s), 913 (m), 896 (sh), $856(\mathrm{~s}), 760(\mathrm{w}), 702(\mathrm{~m}), 682(\mathrm{w}), 645(\mathrm{~m}), 479(\mathrm{~m})$.

\subsection{X-ray Crystallography}

Data collection was carried out by using a Bruker Nonius X8 APEX 2 diffractometer equipped with a CCD bi-dimensional detector using the monochromatized wavelength $\lambda(\mathrm{Mo} \mathrm{K} \alpha)=0.71073 \AA$. Absorption correction was based on multiple and symmetry-equivalent reflections in the data set using the SADABS program [29] based on the method of Blessing [30]. The structures were solved by direct methods and refined by full-matrix least-squares using the SHELX-TL package [31]. In all structures, there are small discrepancies between the formulae determined by elemental analysis and those deduced from the crystallographic atom list because of the difficulty in locating all disordered water molecules (and also the counter-cations in some cases). In the structures of $\mathbf{N H}_{4} \mathbf{M o}_{6}\left(\mathbf{A l e P y}_{2} \mathbf{M o}\right)_{2}$, $\mathrm{NH}_{4}{ }^{+}$and $\mathrm{H}_{2} \mathrm{O}$ could not be distinguished based on the observed electron densities; therefore, all the positions were labeled $\mathrm{O}$ and assigned the oxygen atomic scattering factor. Crystallographic data are given in Table 2. Partial atomic labeling schemes, selected bond distances and bond valence sum calculations [32] are reported in Figure S1.

Table 2. Crystallographic data.

\begin{tabular}{|c|c|c|c|}
\hline Parameters & $\mathrm{NaMo}_{6}(\mathrm{Ale}-4 \mathrm{Py})_{2}$ & $\mathrm{NaKMo}_{6}(\mathrm{Ale}-4 \mathrm{Py})_{2}$ & $\mathrm{NH}_{4} \mathrm{Mo}_{6}\left(\mathrm{AlePy}_{2} \mathrm{Mo}\right)_{2}$ \\
\hline Formula & $\mathrm{C}_{20} \mathrm{H}_{58} \mathrm{~N}_{4} \mathrm{Mo}_{6} \mathrm{Na}_{4} \mathrm{O}_{45} \mathrm{P}_{4}$ & $\mathrm{C}_{20} \mathrm{H}_{56} \mathrm{~N}_{4} \mathrm{~K}_{3.5} \mathrm{Mo}_{6} \mathrm{Na}_{0.5} \mathrm{O}_{44} \mathrm{P}_{4}$ & $\mathrm{C}_{32} \mathrm{H}_{108} \mathrm{~N}_{14} \mathrm{Mo}_{8} \mathrm{O}_{56} \mathrm{P}_{4}$ \\
\hline Formula weight $/ \mathrm{g} \mathrm{mol}^{-1}$ & 1866.16 & 1904.53 & 2476.67 \\
\hline Crystal system & triclinic & triclinic & triclinic \\
\hline Space group & $P-1$ & $P-1$ & $P-1$ \\
\hline$a / \AA$ & $9.0240(3)$ & $17.9501(5)$ & $17.602(2)$ \\
\hline$b / \AA$ & $19.4282(6)$ & $19.4745(4)$ & $22.134(2)$ \\
\hline$c / \AA$ & $21.1568(7)$ & $19.8487(5)$ & $28.323(3)$ \\
\hline$\alpha /^{\circ}$ & $103.992(2)$ & $76.188(1)$ & $97.443(5)$ \\
\hline$\beta /{ }^{\circ}$ & $95.5612(2)$ & $69.590(1)$ & $95.464(5)$ \\
\hline$\gamma /{ }^{\circ}$ & $103.407(1)$ & $76.669(1)$ & $107.430(5)$ \\
\hline$V / \AA^{3}$ & $3454.8(2)$ & $6231.6(3)$ & $10334(2)$ \\
\hline$Z$ & 2 & 4 & 4 \\
\hline$D_{\text {calc }} / \mathrm{g} \mathrm{cm}^{-3}$ & 1.813 & 2.028 & 1.560 \\
\hline$\mu / \mathrm{mm}^{-1}$ & 1.273 & 1.616 & 1.087 \\
\hline Data/parameters & $12208 / 865$ & $36431 / 1558$ & $36283 / 2119$ \\
\hline$R_{\text {int }}$ & 0.0301 & 0.0429 & 0.0467 \\
\hline GOF & 1.023 & 1.070 & 1.035 \\
\hline$R_{1}(I>2 \sigma(\mathrm{I}))$ & 0.0710 & 0.0568 & 0.1051 \\
\hline$w R_{2}$ & 0.1960 & 0.1649 & 0.2719 \\
\hline
\end{tabular}




\subsection{Physical Methods}

Infrared (IR) spectra were recorded on a Nicolet 30 ATR 6700 FT spectrometer. EDX measurements were performed on a JEOL JSM 5800LV apparatus. The ${ }^{31} \mathrm{P}$ NMR spectra were recorded on a Brüker AC-300 spectrometer operating at $121.5 \mathrm{MHz}$ in $5-\mathrm{mm}$ tubes with ${ }^{1} \mathrm{H}$ decoupling. ${ }^{31} \mathrm{P}$ NMR chemical shifts were referenced to the external usual standard $85 \% \mathrm{H}_{3} \mathrm{PO}_{4}$. Diffuse reflectance spectra were collected at room temperature on a finely ground sample with a Cary $5 \mathrm{G}$ spectrometer (Varian) equipped with a $60 \mathrm{~mm}$ diameter integrating sphere and computer control using the "Scan" software. Diffuse reflectance was measured from 250-1000 nm with a $2 \mathrm{~nm}$ step using Halon powder (from Varian) as reference (100\% reflectance). The reflectance data were treated by a Kubelka-Munk transformation [33] to better locate the absorption thresholds. The samples were irradiated with a Fisher Bioblock labosi UV lamp $\left(\lambda_{\operatorname{exc}}=365 \mathrm{~nm}, 6 \mathrm{~W}\right)$ at a distance of $50 \mathrm{~mm}$.

\section{Conclusions}

In summary, the synthesis of two novel molybdobisphosphonate complexes with BPs functionalized by pyridine groups has been performed by a one step or two step procedure in water. These POMs have been characterized in the solid state by single crystal X-ray diffraction and in solution by ${ }^{31} \mathrm{P}$ NMR spectroscopy. $\mathbf{N H}_{4} \mathbf{M o}_{6}\left(\mathbf{A l e P y}_{2} \mathbf{M o}_{2}\right.$ is the ammonium salt of the mixed-valent anion $\left[\left(\mathrm{Mo}_{2} \mathrm{O}_{4}\right)\left(\mathrm{Mo}^{\mathrm{VI}} \mathrm{O}_{6}\right)_{2}(\mathrm{AlePy})_{2}\left(\mathrm{Mo}^{\mathrm{VI}} \mathrm{O}_{3}\right)_{2}\right]^{8-}$ in which the two pyridine arms of each $\mathrm{BP}$ ligand chelate an additional $\mathrm{Mo}^{\mathrm{VI}}$ ion. $\left[\left(\mathrm{Mo}_{3} \mathrm{O}_{8}\right)_{2}(\mathrm{O})(\mathrm{Ale}-4 \mathrm{Py})_{2}\right]^{4-}\left(\mathbf{M o}_{6}(\mathbf{A l e}-4 \mathrm{Py})_{2}\right)$ crystallizes as a pure $\mathrm{Na}$ salt and as a mixed $\mathrm{Na} / \mathrm{K}$ salt. Although the nature of the alkali counter-ions is different in the two salts and thus the 3D structure, the hydrogen bonding networks involving the $\mathbf{M o}_{6}(\mathbf{A l e}-\mathbf{4 P y})_{2}$ units are quite similar. This strongly impacts the photochromic properties of both compounds. Noticeably, $\mathrm{NaMo}_{6}(\mathrm{Ale}-4 \mathrm{Py})_{2}$ and $\mathrm{NaKMo}_{6}(\mathrm{Ale}-4 \mathrm{Py})_{2}$ exhibit remarkably fast and quite comparable color-change effects from white to deep purple under UV excitation, and to date they are the most efficient known photochromic organoammonium/POM systems. Their highly solid-state photochromic performances in ambient conditions can be correlated to a great number of $\mathrm{N}-\mathrm{H} \cdots \mathrm{O}$ contacts between the oxygen atoms of the hexanuclear units and the organoammonium groups of the Ale-4Py ligands as well as the presence of the diprotonated amino groups.

\section{Acknowledgments}

This work was supported by CNRS, UVSQ and the French ANR (grant ANR-11-BS07-011-01BIOOPOM). Guillaume Rousseau, Bertrand Gaulupeau and Noura Saada are gratefully acknowledged for their participation to the synthesis of the compounds.

\section{Author Contributions}

The synthesis and characterizations of the compounds were performed by Tarik Benali and Olivier Oms. Characterization by single crystal X-ray diffraction was performed by Jérôme Marrot. Photochromic properties were studied by Marin Puget, Hélène Serier-Brault, Philippe Deniard, and Rémi Dessapt. Full research and methodology were provided by Olivier Oms, Pierre Mialane and Anne Dolbecq. The preparation of the manuscript was made by Olivier Oms, Anne Dolbecq and Rémi Dessapt. 


\section{Conflicts of Interest}

The authors declare no conflict of interest.

\section{References}

1. Clemente-Juan, J.M.; Coronado, E.; Gaita-Ariño, A. Magnetic Polyoxometalates: from Molecular Magnetism to Molecular Spintronics and Quantum Computing. Chem. Soc. Rev. 2012, 41, 7464-7478.

2. Hasenknopf, B. Polyoxometalates: Introduction to a Class of Inorganic Compounds and their Biomedical Applications. Front. Biosci. 2005, 10, 275-287.

3. Song, Y.-F.; Tsunashima, R. Recent Advances on Polyoxometalate-based Molecular and Composite Materials. Chem. Soc. Rev. 2012, 41, 7384-7402.

4. Kawata, S.; Kawata, Y. Three-Dimensional Optical Data Storage Using Photochromic Materials. Chem. Rev. 2000, 100, 1777-1788.

5. Yamase, T. Photo- and Electrochromism of Polyoxometalates and Related Materials. Chem. Rev. 1998, 98, 307-325.

6. Dessapt, R.; Collet, M.; Coué, V.; Bujoli-Doeuff, M.; Jobic, S.; Lee, C.; Whangbo, M.-H. Kinetics of Coloration in Photochromic Organoammonium Polyoxomolybdates. Inorg. Chem. 2009, 48, 574-580.

7. Dolbecq, A.; Dumas, E.; Mayer, C.R.; Mialane, P. Hybrid Organic-Inorganic Polyoxometalate Compounds : From Structural Diversity to Applications. Chem. Rev. 2010, 110, 6009.

8. Proust, A.; Matt, B.; Villanneau, R.; Guillemot, G.; Gouzerh, P.; Izzet, G. Functionalization and Post-functionalization : a Step Towards Polyoxometalate-based Materials. Chem. Soc. Rev. 2012, 41, 7605-7622.

9. Musumeci, C.; Luzio, A.; Pradeep, C.P.; Miras, H.N.; Rosnes, M.H.; Song, Y.-F.; Long, D.-L.; Cronin, L.; Pignataro, B. Programmable Surface Architectures Derives from Hybrid Polyoxometalate-Based Clusters. J. Phys. Chem. C 2011, 115, 4446-4455.

10. Errington, R.J.; Petkar, S.S.; Horrocks, B.R.; Houlton, A.; Lie, L.H.; Patole, S.N. Covalent Immobilization of a TiW5 Polyoxometalate on Derivatized Silicon Surfaces. Angew. Chem. Int. Ed. 2005, 44, 1254-1257.

11. Geisberger, G.; Gyenge, E.B.; Hinger, D.; Bösiger, P.; Maake, C.; Patzke, G.R. Synthesis, Characterization and Bioimaging of Fluorescent Labeled Polyoxometalates. Dalton Trans. 2013, 42, 9914-9920.

12. Li, J.; Huth, I.; Chamoreau, L.M.; Hasenknopf, B.; Lacôte, E.; Thorimbert, S.; Malacria, M. Insertion of Amides into a Polyoxometalate. Angew. Chem. Int. Ed. 2009, 48, 2035.

13. Du, D.-Y.; Qin, J.-S.; Li, S.-L.; Su, Z.-M.; Lan, Y.-Q. Recent Advances in Porous Polyoxometalatebased Metal-Organic Framework Materials. Chem. Soc. Rev. 2014, 43, 4615-4632.

14. Dolbecq, A.; Mialane, P.; Sécheresse, F.; Keita, B.; Nadjo, L. Functionalized Polyoxometalates with covalently linked bisphosphonate, N-donor or Carboxylate Ligands: From Electrocatalytic to Optical Properties. Chem. Commun. 2012, 48, 8299-8316. 
15. Banerjee, A.; Bassil, B.S.; Röschenthaler, G.-V.; Kortz, U. Diphosphates and Diphosphonates in Polyoxometalate Chemistry. Chem. Soc. Rev. 2012, 41, 7590-7604.

16. Compain, J.-D.; Mialane, P.; Marrot, J.; Sécheresse, F.; Zhu, W.; Oldfield, E.; Dolbecq, A. Tetra- to Dodecanuclear Oxomolybdate Complexes with Functionalized Bisphosphonate Ligands: Activity in Killing Tumor Cells. Chem. Eur. J. 2010, 16, 13741-13748.

17. El Moll, H.; Zhu, W.; Oldfield, E.; Rodriguez-Albelo, L.M.; Mialane, P.; Marrot, J.; Vila, N.; Mbomekallé, I.-M.; Rivière, E.; Duboc, C.; Dolbecq, A. Polyoxometalates Functionalized by Bisphosphonate Ligands: Synthesis, Structural, Magnetic, and Spectroscopic Characterizations and Activity on Tumor Cell Lines. Inorg. Chem. 2012, 51, 7921-7931.

18. El Moll, H.; Dolbecq, A.; Mbomekallé, I.-M.; Marrot, J.; Deniard, P.; Dessapt, R.; Mialane, P. Tuning the Photochromic Properties of Molybdenum Bisphosphonate Polyoxometalates. Inorg. Chem. 2012, 51, 2291-2302.

19. Dolbecq, A.; Compain, J.-D.; Mialane , P.; Marrot, J.; Sécheresse, F.; Keita, B.; Brudna Holzle, L.R.; Miserque, F.; Nadjo, L. Hexa- and Dodecanuclear Polyoxomolybdate Cyclic Compounds: Application toward the Facile Synthesis of Nanoparticles and Film Electrodeposition. Chem. Eur. J. 2009, 15, 733-741.

20. Banerjee, A.; Raad, F.S.; Vankova, N.; Bassil, B.S.; Heine, T.; Kortz, U. Polyoxomolybdodiphosphonates : Examples Incorporating Ethylenepyridines. Inorg. Chem. 2011, 50, 11667-11675.

21. Modec, B.; Brenčič, J.V. From Small $\left\{\mathrm{Mo}_{2} \mathrm{O}_{4}\right\}^{2+}$ Aggregates to Infinite Solids. J. Clust. Sci. 2002, 13, 279-302.

22. Pope, M.T.; Müller, A. Polyoxometalate Chemistry: An Old Field with New Dimensions in Several Disciplines. Angew. Chem. Int. Ed. Engl. 1991, 30, 34-48

23. Sergienko, V.S. Structural Chemistry of 1-Hydroxyethylidenediphosphonic Acid Complexes. Russ. J. Coord. Chem. 2001, 27, 681-710.

24. Tan, H.; Chen, W.; Liu, D.; Feng, X.; Li, Y.; Yan, A.; Wang, E. Two DiphosphonateFunctionalized Asymmetric Polyoxomolybdates with Catalytic Activity for Oxidation of Benzyl Alcohol to Benzaldehyde. Dalton Trans. 2011, 40, 8414-8418.

25. Coué, V.; Dessapt, R.; Bujoli-Doeuff, M.; Evain, M.; Jobic, S. Synthesis, characterizations and photochromic properties of hybrid organic-inorganic materials based on molybdate, DABCO and piperazine. Inorg. Chem. 2007, 46, 2824-2835.

26. Yang, L.; Zhou, Z.; Ma, P.; Wang, J.; Niu, J. Assembly of Dimeric and Tetrameric Complexes of Polyoxomolybdobisphosphonates Built from $\left[\left(\mathrm{Mo}_{3} \mathrm{O}_{8}\right)\left\{\mathrm{O}_{3} \mathrm{PC}(\mathrm{O})\left(\mathrm{CH}_{2}-3-\mathrm{C}_{5} \mathrm{NH}_{5}\right) \mathrm{PO}_{3}\right\}\right]^{2-}$ Subunits. Cryst. Growth Des. 2013, 13, 2540-2547.

27. Kubícek, V.; Kotek, J.; Hermann, P.; Lukeš, I. Aminoalkylbis(phosphonates): Their Complexation Properties in Solution and in the Solid State. Eur. J. Inorg. Chem. 2007, 333-344.

28. De Rosales, R.T.M.; Finucane, C.; Mather, S.J.; Blower, P.J. Bifunctional Bisphosphonate Complexes for the Diagnosis and Therapy of Bone Metastases. Chem. Commun. 2009, 4847-4849.

29. Sheldrick, G.M. SADABS; Program for Scaling and Correction of Area detector data; University of Göttingen: Germany, 1997.

30. Blessing, R. An Empirical Correction for Absorption Anisotropy Acta Crystallogr. 1995, A51, 33-38. 
31. Sheldrick, G.M. SHELX-TL, version 5.03; Software Package for the Crystal Structure Determination; Siemens Analytical X-ray Instrument Division: Madison, WI, USA, 1994.

32. Brese, N.E.; O'Keeffe, M. Bond Valence Parameters for Solids. Acta Crystallogr. Sect. B 1991, 47, 192-197.

33. Kubelka, P.; Munk, F. An Article on Optics of Paint Layers. Z. Techn. Physik 1931, 12, 593-601.

(C) 2015 by the authors; licensee MDPI, Basel, Switzerland. This article is an open access article distributed under the terms and conditions of the Creative Commons Attribution license (http://creativecommons.org/licenses/by/4.0/). 